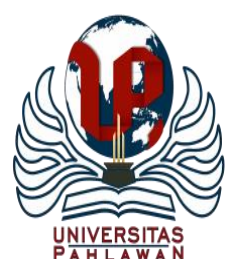

Jurnal Abdidas Volume 2 Nomor 4 Tahun 2021 Halaman 730-736

JURNAL ABDIDAS

http://abdidas.org/index.php/abdidas

\title{
Sosialisasi Penerapan Protokol Kesehatan di SD Negeri 10 Gu Buton Tengah
}

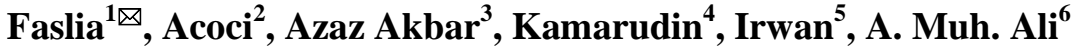 \\ Pendidikan Guru Sekolah Dasar, Universitas Muhammadiyah Buton, Indonesia ${ }^{1,2,3,4,5,6}$ \\ E-mail : dra.faslia13@gmail.com ${ }^{1}$, acoci.acoc12@gmail.com ${ }^{2}$, azaz.akbar23@gmail.com ${ }^{3}$, \\ akamarudin1543@gmail.com ${ }^{4}$, irwanlatif@gmal.com ${ }^{5}$, andiali649@gmail.com ${ }^{6}$
}

\begin{abstract}
Abstrak
Sekolah dasar yang menerapkan pembelajaran secara langsung sangat rentan dengan peningkatan kasus penyebaran Covid-19. Sekolah dasar sebagai penyumbang jumlah terbesar kasus Covid-19, sehingga perlunya pihak untuk memberikan pendampingan untuk menekan laju penyebaran Covid-19 di Indonesia. Sasaran pada kegiatan ini adalah SD Negeri 10 Gu Buton Tengah. Metode kegiatan terdiri dari 2 pendekatan yakni sosialisasi dalam bentuk ceramah/pemaparan materi dan dalam bentuk demonstrasi. Sosialisasi hari pertama kepada guru terdiri dari; pemaparan materi yang disajikan yaitu pemberian semangat untuk terus mendedikasikan diri dalam mencerdaskan anak bangsa; sosialisasi tentang tata cara hidup yang sehat; sosialisasi dengan materi yang berhubungan dengan penerapan protokol kesehatan dan hidup bersih dan sehat; demonstrasi protokol kesehatan, seperti cara mencuci tangan yang tepat melalui air mengalir serta menggunakan cairan pembersih berupa hand sanitizer, dan cara penggunaan masker yang aman dan sehat. Kegiatan hari berikutnya yang ditujukan kepada siswa terdiri dari; senam pagi, demonstrasti cara mencuci tangan yang benar, cara bersin dan batuk sesuai standar WHO, prosedur ketika hendak memasuki ruang kelas, kepatuhan untuk senantiasa menjaga jarak. Kegiatan ini berjalan dengan baik, guru menerapkan protokol kesehatan, sedang siswa mematuhi protokol kesehatan dan pola hidup bersih dan sehat.
\end{abstract}

Kata kunci: sosialisasi, protokol kesehatan, Covid-19

Abstract

Elementary schools that apply direct learning are very vulnerable to the increase in cases of the spread of Covid-19. Elementary schools are the largest contributor to the number of Covid-19 cases, so there is a need for parties to provide assistance to suppress the spread of Covid-19 in Indonesia. The targets of this activity are $10 \mathrm{Gu}$ Buton Tengah Elementary school. The activity method consists of 2 approaches, namely socialization in the form of lectures / presentations of material and in the form of demonstrations. The first day of socialization to teachers consisted of: presentation of the material presented, namely giving encouragement to continue to dedicate themselves to educating the nation's children, socialization about healthy living procedures, socialization with materials related to the application of health protocol and live clean and healthy, demonstration of health protocols, such as how to wash hands properly through running water and use cleaning fluid in the form of hand sanitizer, and how to use masks that are safe and healthy. The next day's activities aimed at students consisted of: morning exercise, demonstration of proper hand washing, how to sneeze and cough according to WHO standards, procedure when entering the classroom, compliance to always keep a distance. This activity went well, the teacher implemented the health protocol, while the students adhered to the health protocol and a clean and healthy lifestyle.

Keywords: Socialization, health protocol, Covid-19

Copyright (c) 2021 Faslia, Acoci, Azaz Akbar, Kamarudin, Irwan, A.Muh.Ali

$\triangle$ Corresponding author

Address : Jln. Betoambari No. 36 Kota Baubau

Email : dra.faslia13@gmail.com

DOI $\quad$ : https://doi.org/10.31004/abdidas.v2i4.355

ISSN 2721- 9224 (Media Cetak)

ISSN 2721- 9216 (Media Online)

Jurnal Abdidas Vol 2 No 4 Tahun 2021 p-ISSN 2721-9224 e-ISSN 2721-9216 
731 Sosialisasi Penerapan Protokol Kesehatan di SD Negeri 10 Gu Buton Tengah - Faslia, Acoci, Azaz Akbar, Kamarudin, Irwan, A.Muh.Ali

DOI: https://doi.org/10.31004/abdidas.v2i4.355

\section{PENDAHULUAN}

Pandemi Covid-19 merupakan musibah global yang menyerang hampir semua negara di dunia tidak terkecuali Indonesia. Wuhan yang merupakan kota pertama yang terkonfirmasi tertular dengan virus ini, tepatnya terjadi pada tanggal 31 Desember 2019 di Negara China (Lee et al., 2020). Sehingga Badan Kesehatan Dunia (WHO) menyebut gejala ini sebagai pandemi global pada tanggal 11 Maret 2020, Indonesia menyebut peristiwa ini sebagai bencana Nasional (Tim Kerja Kementerian Dalam Negeri, 2020).

Covid-19 adalah penyakit yang menular dan penyebaranya bisa melalui bersin, percikan ludah, batuk dari orang yang terinfeksi, virus terhirup oleh orang terdekat, virus masuk melalui mulut, hidung, mata dari tangan yang telah memegang permukaan benda yang terkena virus, penyakit ini juga jika jatuh pada permukaan benda, maka ia dapat bertahan hingga sembilan hari (Apriliany et al., 2021).

Saat ini, pendidikan yang terjadi di Indonesia mengalami pergeseran. Akibat Covid19, kebijakan, model, metode, sampai pada sistem pendidikan seakan berubah $180^{\circ}$. Melalui Kementerian Pendidikan dan Kebudayaan, pemerintah menerapkan kebijakan dengan mempertimbangkan zona dari setiap daerah. Zona merah, oranye dan kuning dengan menerapkan kebijakan learning from home atau belajar dari rumah, sedangkan pada zona hijau dengan melakukan pembelajaran tatap muka dengan menerapkan protokol kesehatan.

Keadaan ini juga berpotensi besar pada penularan Covid-19 kepada daerah yang dinilai sebagai daerah yang kategori zona Hiaju. Dimana pembelajaran pada zona ini memberlakukan pembelajaran secara tatap muka dengan standar yang protokol kesehatan.

Beberapa artikel seperti dikemukakan dalam pemberitaan Kompas pada deskripsi link https://health.kompas.com/read/2020/04/02/08000 0468/anak-anak-tidak-rentan-terhadap-viruscorona-tetapi?page=all menyebutkan bahwa covid19 tidak rentan pada anak dikarenakan kekebalan tubuh pada anak sangat kuat. Namun pada informasi yang kedua seperti dikutip pada Kompas.com, yang ditulis oleh Irawan Sapto Adhi, Ikatan Dokter Anak Indonesia (IDAI) menemukan fakta bahwa jumlah anak yang terpapar Covid-19 di Indonesia tergolong tinggi.

Dilanjutkan dengan pemberitaan oleh Detikhealth pada Selasa, 30 Mar 2021 bahwa Satgas Ungkap Sebaran Kasus COVID-19 pada Anak, Terbanyak adalah Usia SD. Sebagaimana dijelaskan oleh kata juru bicara Satgas Penanganan COVID-19 Prof Wiku Adisasmito, dalam konferensi pers, Selasa (30/3/2021) bahwa jumlah penuliran covid-19 pada anak sekolah adalah sebagai berikut : (1) 0-2 tahun (PAUD) : 23.934 orang, (2) 3-6 tahun (TK) : 25.219 orang, (3) 7-12 tahun (SD) : 49.962 orang, (4) 13-15 tahun (SMP) : 36.634 orang, (5) 16-18 tahun (SMA) : 45.888 orang. Data tersebut menunjukkan bahwa anak dengan rentan usia antara 7-12 tahun menjadi penderita covid-19 terbanyak, itu menunjukkan bahwa usia sekolah dasar menjadi penderita covid19 terbanyak di Indonesia.

Upaya untuk menekan penyebaran virus COVID-19 adalah dengan komitmen pemerintah 
732 Sosialisasi Penerapan Protokol Kesehatan di SD Negeri 10 Gu Buton Tengah - Faslia, Acoci, Azaz Akbar, Kamarudin, Irwan, A.Muh.Ali

DOI: https://doi.org/10.31004/abdidas.v2i4.355

Indonesia untuk menekankan sebuah kebijakan yang serius untuk memutus lingkaran musibah global ini dengan memberikan himbauan kepada masyarakat Indonesia agar merapkan program 3M (memakai masker, mencuci tangan atau penggunakan hand sanitizer, menjaga jarak) (Apriliany et al., 2021). Persoalan yang muncul pada penerapan program $3 \mathrm{M}$ oleh pemerintah terjadi pada anak sekolah dasar yang notabene sebagai penderita penyakit covid-19 terbesar pada tingkatan sekolah di Indonesia.

Karakter yang terjadi pada anak sekolah dasar cenderung bermain dan belajar. Beban yang berat pada sekolah terkadang mengurangi hak-hak mereka untuk bermain. Sehingga yang terjadi mereka cenderung malas dan bosan pada saat belajar di dalam kelas, karena mereka menghadapi situasi pembelajaran yang nyaris sama (Sari, 2012). Anak usia SD dalam tingkat perkembangannya sangat memerlukan perhatian khusus baik dari orang tua maupun guru. Senada dengan itu, Kurni menjelaskan bahwa Anak usia SD adalah anak yang berada pada rentang usia 6 sampai 13 tahun dengan karakteristiknya yang unik dan sedang menempuh pendidikan jenjang SD/MI (Trianingsih, 2016).

Dengan demikian maka pencegahan penularan Covid-19 perlu dilakukan pada anak sekolah dasar dengan dasar pertimbangan penularan yang cukup tinggi dan pertimbangan karakter yang cenderung bermain. Program pemerintah dengan menerapkan 3-M perlu menjadi kesadaran kolektif, tidak hanya diketahui guru dan orang tua, tetapi jauh dari itu adalah mampu diterapkan oleh peserta didik, baik ketika sedang berada di lingkungan sekolah maupun di lingkungan masyarakat maupun keluarga.

Oleh karena itu perlu dilkukan pendampingan kepada siswa sekolah dasar untuk membangun kesadaran berupa pembiasaan untuk menerapkan program 3-M dari pemerintah. Sehingga peserta didik mampu menjaga kesehatan dan mampu menjalankan program 3-M dari pemerintah yang pada akhirnya berdampak pada penekanan laju penularan Covid-19.

\section{METODE}

Objek dalam pengabdian ini adalah guru, tenaga pendidik dan siswa di SD Negeri $10 \mathrm{Gu}$ Buton Tengah. Berlangsung pada tanggal 21-22 Januari 2021. Prosedur pelaksanaan kegiatan pengabdian ini agar dapat terealisasi adalah dengan melakukan sosialisasi kepada guru terkait dengan penerapan 3-M kepada guru dan tenaga pendidik di sekolah dasar. Langkah awal yang dilkaukan pada tahap ini adalah dengan melakukan persiapan. Persiapan yang dilakukan adalah materi operasional program 3-M yang dapat disampaikan kepada guru dan tenaga pendidik.

Tahap selanjutnya adalah dengan melakukan sosialisasi langsung kepada guru dengan cara pembagian slide, dimana pada saat penjelasan peserta juga memperhatikan slide yang sudah dibagikan, sehingga tercipta hubungan yang aktif. Diharapkan dengan parcipatory ini peserta sosialisasi dapat memahami apa yang menjadi sasaran isi dari program 3-M oleh pemerintah. Kegiatan ini digunakan dalam mensosialisasikan peraturan pemerintah terkait panduan pelaksanaan pendidikan dan penerapan protokol kesehatan 
733 Sosialisasi Penerapan Protokol Kesehatan di SD Negeri 10 Gu Buton Tengah - Faslia, Acoci, Azaz Akbar, Kamarudin, Irwan, A.Muh.Ali

DOI: https://doi.org/10.31004/abdidas.v2i4.355

dimasa new normal, diantaranya tata cara penyelenggaraan pembelajaran dimasa pandemi, langkah penerapan protokol kesehatan seperti cara mencuci tangan yang benar, cara memakai dan melepas masker, aturan maksimal lamanya penggunaan masker, pembatasan interaksi sosial, serta etika batuk dan bersin.

Kegiatan edukasi kepada peserta didik dilakukan dengan cara demonstrasi yaitu digunakan untuk mengajari peserta dengan cara menceritakan dan memperagakan suatu langkahlangkah protokol kesehatan. Demonstrasi merupakan praktek yang diperagakan kepada peserta. Karena itu, demonstrasi dapat dibagi menjadi dua tujuan: demonstrasi proses untuk memahami langkah demi langkah dan demonstrasi hasil untuk memperlihatkan atau memperagakan hasil dari sebuah proses. Setelah demonstrasi dilanjutkan dengan praktek oleh peserta sendiri.

Kegiatan terakhir dengan melakukan evaluasi. Evaluasi yang dimaksud adalah meninjau keberhasilan pelaksanaan pendampingan sekaligus membagikan masker kepada guru dan siswa di SD Negeri 10 Gu Buton Tengah.

\section{HASIL DAN PEMBAHASAN}

Pembelajaran secara langsung ditengah kepungan virus sangat berbahaya jika tidak dilandasi dengan pengetahuan dan komitmen dari semua unsur. Guru sebagai penggerak proses belajar mengajar yang berlangsung di sekolah sangat berperan penting dalam mewujudkan keadaan yang kondusif sehingga sangat dimungkinkan untuk diberikan pengetahuan yang memadai dan komitmen yang tinggi untuk menciptakaan keadaan yang lebih baik. Guru harus mendukung program pemerintah yang menekan laju penyebaran Covid-19 mengingat peran ini sangat penting maka perlu dilakukan penyegaran kesadaran kepada guru untuk meningkatkan partisipasi dalam mendorong terealisasinya program $3 \mathrm{M}$ oleh pemerintah.

Sosialisasi kepada guru masih merupakan jalan yang efektif untuk dilakukan akademisi dalam mendorong terealisasinya program 3-M. Mengingat informasi edukasi ini tidak diketahui oleh semua unsur sehingga perlu adanya kegiatan yang mewujudkan kesadaran kolektif.

Pembelajaran tatap muka secara langsung dilingkungan sekolah perlu adaptasi pembiasaan baru kepada siswa. Seperti halnya guru yang perlu disampaikan untuk terlaksananya program 3-M pemerintah, maka siswa juga harus dilibatkan untuk membangun kesadaran untuk menjalankan protokol kesehatan, baik ketika sedang di lingkungan sekolah, maupun ketika berada dilingkungan rumah. Kecenderungan anak yang bermain memungkinkan penyebaran Covid-19 yang masih, sehingga untuk menekan keadaan ini perlu internalisasi yang dibangun ukepada siswa untuk mewujudkan kesadaran untuk menjalankan protokol kesehatan, baik di lingkungan sekolah maupun lingkungan keluarga.

Pelaksanaan pengabdian ini berangkat dari sebuah analisis hasil survei singkat yang dilakukan oleh peserta magang III mahasiswa Pendidikan Guru Sekolah Dasar (PGSD) Universitas Muhammadiyah Buton, sehingga menilai perlu antisipasi sedini mungkin untuk mencekah penularan yang masif. 
734 Sosialisasi Penerapan Protokol Kesehatan di SD Negeri 10 Gu Buton Tengah - Faslia, Acoci, Azaz Akbar, Kamarudin, Irwan, A.Muh.Ali

DOI: https://doi.org/10.31004/abdidas.v2i4.355

Survei awal oleh peserta magang III dilakukan di SD Negeri $10 \mathrm{Gu}$ Buton Tengah. Kegiatan ini dimulai dengan survei dan membangun komunikasi awal dengan pihak sekolah utnuk dilakukan kegiatan. Setelah terjadi kesepakatan, dengan pertimbangan waktu yang tersedia yang tidak mengganggu proses belajar mengajar di kelas maka disepakati kegiatan berlangsung 2 hari dengan durasi waktu 2 Jam setiap harinya.

Pada hari pertama sosialisasi dilakukan di ruang guru dengan mendemonstrasikan tata cara hidup yang sehat dengan memberikan bsejumlah materi yang dirangkum dari kajian tim satgas Covid-19. Materi yangdisajikan terdiri dari pemberian semangat untuk terus mendedikasikan diri dalam mencerdaskan anak bangsa, lalu dilanjutkan dengan materi yang berhubungan dengan penerapan protokol kesehatan dan hidup bersih dan sehat, disampaikan pula tata cara penerapan protokol kesehatan yang benar dan manfaatnya, seperti cara mencuci tangan yang tepat melalui air mengalir serta menggunakan cairan pembersih berupa hand sanitizer, cara penggunaan masker yang aman dan sehat.

Hari kedua adalah melakukan sosialisasi kepada peserta didik. Beberapa hal dasar yang disampaikan sebelum melakukan demonstrasi kepaa peserta didik hampir serupa dengan yang disampaikan kepada guru tetapi pada siswa hanya menekankan pada pembatasan sosial yang senantiasa mematuhi untuk menjaga jarak 1,5 meter sesuai dengan anjuran satgas Covid-19 juga melarang untuk menghindari kontak langsug yang berhubungan dengan daerah muka/wajah setelah beraktifitas. Memperhatikan etika dalam bersin dan batuk dengan menutup area hidung dan mulut dengan lengan atau dengan mantuan tisu.

Kegiatan sosialisasi kepada siswa selain pada poin di atas, juga dilakukan demonstrasi protokol kesehatan dan pola hidup sehat. Kegiatan ini salah satunya dengan melakukan peragaan senam di SD Negeri 10 Gu Buton Tengah. Kegiatan ini merupakan permintaan dari salah seorang murid yang sangat antusias dalam kegiatan sosialisasi, mengingat bahwa kebugaran dan kesehatan anak harus tetap terjaga. Maka, untuk menjaga kebugaran anak-anak dilaksanakan senam sehat. Kegiatan ini disambut meriah oleh peserta didik dengan dipandu oleh salah seorang guru yang sudah dipercayakan mendampingi pelaksanaan kegiatan pengabdian ini di SD Negeri $10 \mathrm{Gu}$ Buton Tengah.

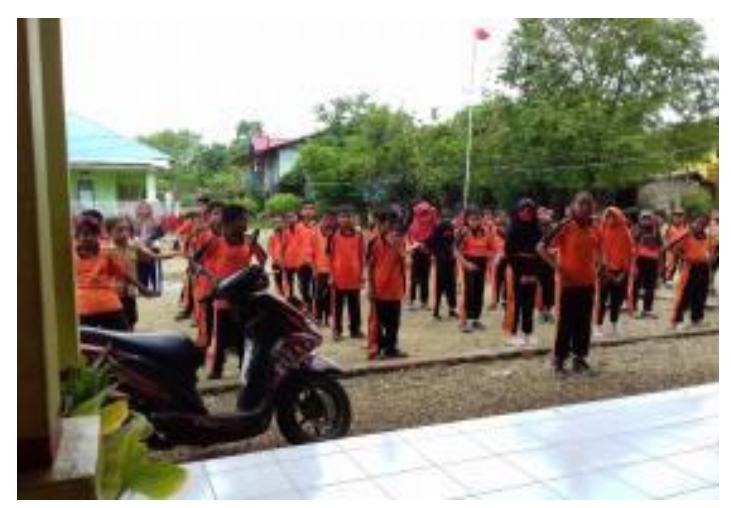

Gambar 1. Kegiatan Senam Pagi

Kegiatan lain yang dilakukan adalah demonstrasi kepada peserta didik untuk rajin mencuci tangan dengan air yang mengalir dengan menggunakan cairan hand sanitizer yang telah disediakan oleh phak sekolah. 
735 Sosialisasi Penerapan Protokol Kesehatan di SD Negeri 10 Gu Buton Tengah - Faslia, Acoci, Azaz Akbar, Kamarudin, Irwan, A.Muh.Ali

DOI: https://doi.org/10.31004/abdidas.v2i4.355

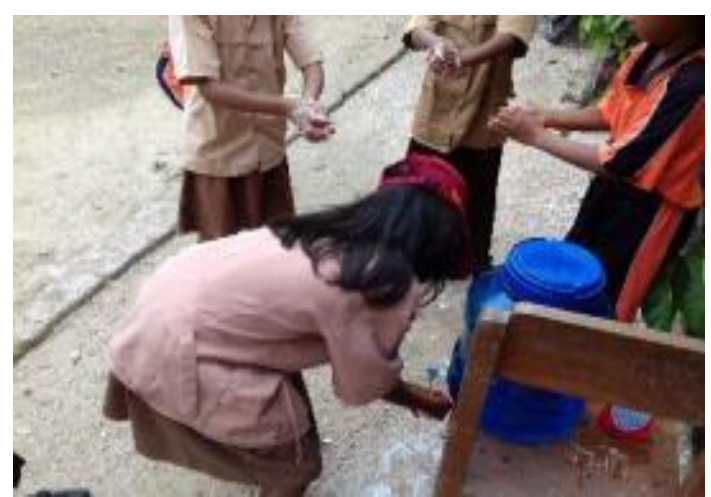

Gambar 2. Demonstrasi Cuci Tangan Pakai Sabun

Kegiatan terakhir pada hari kedua adalah dengan menjelaskan penerapan protokol kesehatan ketika memasuki ruangan kelas dengan tetap menjaga jarak sesuai dengan anjuran yang sudah ditetapkan.

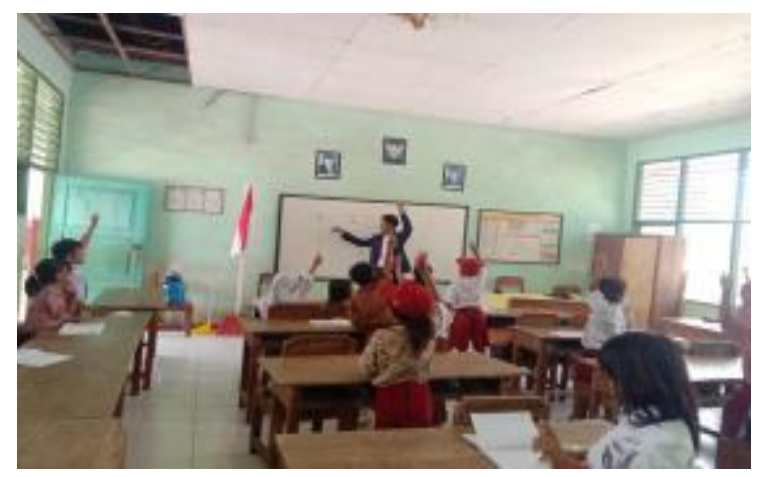

Gambar 3. Penjelasan tentang Prokes

Kegiatan ini dilakukan dengan harapan agar siswa yang melaksanakan proses pembelajaran di ruang kelas tetap menjaga protokol kesehatan dan tetap semangat untuk mengikuti prose belajar yangajar yang dibawakan oleh guru kelas maupun guru mata pelajaran.

Pada kegiatan ini peserta didik diminta untuk menjaga jarak dan mengangkat tanganya sebagai bentuk atensi dan kesanggupan mereka untuk menjalankan program-program yang mendukung terlaksananya agenda pemerintah yang menekan penyebaran covid-19 yang terus meningkat di berbagai daerah di Indonesia.

Setelah pelaksanaan pendampingan, baik kepada guru maupun siswa, maka dilakukan evaluasi untuk melihat sejauh mana ketercapaian program yang telah dilakukan. Hasil evaluasi dari kegiatan ini menunjukkan bahwa guru telah menerapkan protokol kesehatan, serta siswa sudah mematuhi protokol kesehatan dan mematuhi etika bersin sesuai dengan standar WHO. Kegiatan akhir pada evaluasi, sebagai bentuk ucapan terimakasih, tim membagikan masker kepada guru dan siswa di SD Negeri $10 \mathrm{Gu}$ Buton Tengah.

Kesimpulan pada kegiatan pengabdian ini yaitu dengan pelaksanaan pendampingan kepada pihak sekolah, maka guru bisa menerapkan protokol kesehatan dalam proses pembelajaran di dalam ruang kelas. Siswa menerapkan protokol kesehatan dengan menjaga jarak ketika berada di ruang kelas, menjaga etika bersin, dan menerapkan pola hidup yang sehat.

\section{SIMPULAN}

Kegiatan ini terdiri dari 2 hari kegaiatan yang dimulai dengan sosialisasi kepada guru dan tenaga pendidik yang terdiri dari : (1) Materi yang disajikan terdiri dari pemberian semangat untuk terus mendedikasikan diri dalam mencerdaskan anak bangsa, (2) sosialisasi tentang tata cara hidup yang sehat, (3) sosialisasi dengan materi yang berhubungan dengan penerapan protokol kesehatan dan hidup bersih dan sehat, (4) Demonstrasi protokol kesehatan, seperti cara mencuci tangan yang tepat melalui air mengalir 
736 Sosialisasi Penerapan Protokol Kesehatan di SD Negeri 10 Gu Buton Tengah - Faslia, Acoci, Azaz Akbar, Kamarudin, Irwan, A.Muh.Ali

DOI: https://doi.org/10.31004/abdidas.v2i4.355

serta menggunakan cairan pembersih berupa hand sanitizer, dan cara penggunaan masker yang aman dan sehat.

Kegiatan pada hari kedua yang ditujukan pada siswa terdiri dari : (1) Senam Pagi, (2) Demonstrasti cara mencuci tangan yang benar, (3) Cara Bersin dan Batuk sesuai standar WHO, (4) Prosedur ketika hendak memasuki ruang kelas, (5) Kepatuhan untuk senantiasa menjaga jarak.

Hasil evaluasi dari kegiatan sosialisasi di SD Negeri $10 \mathrm{Gu}$ Buton Tengah menunjukkan perubahan perilaku guru dengan menerapkan protokol kesehatan dan perilaku siswa yang sudah mematuhi protokol kesehatan serta menjaga pola hidup bersih dan sehat sesuai dengan standar WHO.

\section{UCAPAN TERIMA KASIH}

Kegiatan ini tidak terlepas dari dukungan dari berbagai pihak, oleh karena itu ucapan terimakasih kepada pihak universitas yang senantiasa mendukung program kegiatan pengabdian ini. Kepada tim yang selalu kompak demi terlaksananya program pengabdian ini. Kepada pihak sekolah yang sudah memfasilitasi kami sehingga program pengabdian ini berjalan sesuai dengan yang kami rencananakan, dan yang terakhir kepada pihak penerbit yang sudah bersedia menerbitkan artikel pengabdian ini sehingga menjadi karya yang bisa dikonsumsi oleh khalayak luas.

\section{DAFTAR PUSTAKA}

Apriliany, F., Umboro, R. O., \& Ersalena, V. F. (2021). Penyuluhan Gema Cermat Obat dan Pelatihan Pembuatan Hand Sanitizer. Jurnal
Abdidas.

Lee, J. Y., Wong, C. P., \& Lee, S. W. H. (2020). $\mathrm{m}$-Health views and perception among Malaysian: findings from a survey among individuals living in Selangor. MHealth. https://doi.org/10.21037/mhealth.2019.09.16

Sari, V. P. (2012). Perbedaan Prestasi Belajar Antara Anak Sekolah Dasar Penderita Obesitas dan Status Gizi Normal. Jurnal Kesehatan Masyarakat.

Tim Kerja Kementerian Dalam Negeri. (2020). Pedoman Umum Menghadapi Pandemi Covid-19 Bagi Pemerintah Daerah. Journal of Chemical Information and Modeling.

Trianingsih, R. (2016). Pengantar Praktik Mendidik Anak Usia Sekolah Dasar. Al Ibtida: Jurnal Pendidikan Guru MI. https://doi.org/10.24235/al.ibtida.snj.v3i2.88 0 